\title{
Trends in the start of the wet season over Africa
}

Article

Published Version

Kniveton, D. R., Layberry, R., Williams, C. J. R. and Peck, M. (2009) Trends in the start of the wet season over Africa. International Journal of Climatology, 29 (9). pp. 1216-1225. ISSN 0899-8418 doi: https://doi.org/10.1002/joc.1792 Available at https://centaur.reading.ac.uk/19286/

It is advisable to refer to the publisher's version if you intend to cite from the work. See Guidance on citing.

To link to this article DOI: http://dx.doi.org/10.1002/joc.1792

Publisher: John Wiley \& Sons

All outputs in CentAUR are protected by Intellectual Property Rights law, including copyright law. Copyright and IPR is retained by the creators or other copyright holders. Terms and conditions for use of this material are defined in the End User Agreement.

\section{www.reading.ac.uk/centaur}

\section{CentAUR}

Central Archive at the University of Reading

Reading's research outputs online 


\title{
Trends in the start of the wet season over Africa
}

\author{
D. R. Kniveton, ${ }^{\text {a* R. Layberry }}{ }^{\mathrm{b}}$, C. J. R. Williams ${ }^{\mathrm{c}}$ and Mika Peck ${ }^{\mathrm{d}}$ \\ ${ }^{a}$ Department of Geography, University of Sussex, Falmer, Brighton, BN1 9QJ, UK \\ ${ }^{\mathrm{b}}$ Environmental Change Institute, University of Oxford, South Parks Road OXFORD OXI 3QY, UK \\ ${ }^{\mathrm{c}}$ Walker Institute, Department of Meteorology, University of Reading, Earley Gate, Reading, RG6 6BB. UK \\ d JMS Building, University of Sussex, Falmer, Brighton BN1 9QJ, UK
}

\begin{abstract}
A quarter of a century of daily rainfall data from the Global Telecommunications System are used to define the temporal and spatial variability of the start of the wet season over Africa and surrounding extreme south of Europe and parts of the Middle East. From 1978 to 2002, the start of the wet season arrived later in the year for the majority of the region, as time progressed. In some parts of the continent, there was an annual increase in the start date of up to 4 days per year. On average, the start of the wet season arrived 9-21 days later from 1978 to 2002, depending on the threshold used to define the start of the rains (varying from 10-30 mm over 2 days, with no dry period in the following 10 days). It is noted that the inter-annual variability of the start of the wet season is high with the range of start dates varying on average from 116 to 142 days dependent on the threshold used to determine the start date. These results may have important implications for agriculturists on all levels (from the individual farmer to those responsible for regional food supply), as knowledge of potential future climate changes starts to play an increasingly important role in the agricultural decision-making process, such as sowing and harvesting times. Copyright @ 2008 Royal Meteorological Society
\end{abstract}

KEY WORDS start of rains; Africa; climate change; wet season

Received 9 July 2007; Revised 26 September 2008; Accepted 27 September 2008

\section{Introduction}

To date, much of the research into variability of rainfall over the African region has focused on monthly and seasonal rainfall totals and their relationship with land surface processes (Otterman, 1974; Fontaine et al., 2002; Gallee et al., 2004) and sea-surface temperatures (SST) over the Atlantic Ocean (Janicot et al., 1998; Vizy and Cook, 2001; Rouault et al., 2003), the Indian Ocean (Goddard and Graham, 1999; Reason, 1999; Cook, 2000), the Pacific Ocean (Nicholson and Entekhabi, 1987; Ogallo, 1988; Camberlin et al., 2001; Cook, 2001), the Mediterranean (Rowell, 2003) and globally (Semazzi et al., 1996). In turn, the discovery and physical understanding of the mechanics of these climate teleconnections have led, via empirical and model-based techniques, to a number of seasonal rain forecasting schemes for the continent (Landman and Mason, 1999; Tennant, 1999; Thiaw et al., 1999; Ntale et al., 2003; Gissila et al., 2004). Unfortunately, however, studies of agricultural users have revealed that the information of most interest to the user is not the rainfall total but the start and end dates of the wet season (Ingram et al., 2003; Ziervogel and Calder, 2003). In particular, the start date of the wet season is of crucial importance as it determines sowing times, with planting too early possibly leading to crop

\footnotetext{
* Correspondence to: D. R. Kniveton, Department of Geography, University of Sussex, Falmer, East Sussex, BN1 9RH, UK.

E-mail: kafw3@ susx.ac.uk
}

failure, and planting too late leading to a reduced growing season and crop yield (Dodd and Jolliffe, 2001). Therefore, clearly there is a need to understand trends in the start of the wet season.

In part, the reduced level of research on the start of the wet season has resulted from the 'fuzzy' nature of the start date. For instance, there is no definitive answer to the question of how much rain and over what particular period defines the start of the wet season. Additionally, the occurrence of dry spells after an initial period of rainfall is considered to signify a false start of the wet season, particularly in terms of sowing dates. Again, the definition of what constitutes a dry spell is open to different interpretations. Despite these difficulties, a number of definitions of the start of the wet season have been put forward (Benoit, 1977; Stern et al., 1982; Hulme, 1987). In Africa, probably the definition with the most widespread use for agro-climatological applications was documented by Stern et al. (1982) and is of the general form: (a) the start of the wet season is not considered until after a particular date, ' $d$ '; (b) the potential start date is defined as the first occurrence of at least ' $x$ ' $\mathrm{mm}$ totalled over ' $t$ ' consecutive days; and (c) the potential start could be a false start if a dry spell of ' $n$ ' or more days in the next ' $m$ ' days occurs afterwards.

The variables $d, x, t, n$ and $m$ can be defined locally according to user requirements. The advantage of this type of definition is that it can be tailored to suit a 
particular crop's water (and hence, in rain-fed agriculture, rainfall) requirements. For instance, in Niger, the planting date for millet was observed by Davy et al. (1976) to coincide with the first occurrence of $20 \mathrm{~mm}$ of rain over a two-day period. In trying to understand possible trends in the start of the wet season, these parameters can be varied to create a historical database of possible start dates of the wet season before extracting coherent climate signals. In this paper, we thus use the above definition to define the variability of start dates of the wet season over Africa, and explore the trends within these data. In Section 2 we describe the derivation of the wet season start date data, while in Section 3 we explore the trends in wet season start dates. In Section 4 the results of the study are discussed.

\section{Rainfall data}

The calculation of the start date of the wet season requires continuous daily raingauge data. Unfortunately, over large parts of Africa and the surrounding land areas of the extreme south of Europe and parts of the Middle East (hereinafter, the whole region is referred simply to as Africa), few long-term daily observations of rainfall exist. One of the few sources of relatively long-term daily raingauge data comes from the Global Telecommunication System (GTS). In Figure 1, the distribution of raingauge data is shown from the GTS network for the period 1978-2002. The rainfall values from these data were spatially interpolated to produce a $2.5^{\circ}$ latitude/longitude daily rainfall dataset for the whole of Africa and checked for spurious data using spatial and temporal outlier tests. These data were obtained from the Climate Prediction Center USAID/FEWS-NET Project at the National Oceanic and Atmospheric Administration (NOAA).

In the general definition of the start of the wet season by Stern et al. (1982), it is suggested that the earliest possible start date, $d$, might be chosen according to previous experience as to whether successful planting had occurred before a particular date, or alternatively, when the probability of a dry spell falls below a certain value. In this study, we have chosen to define $d$ more generally, as the average daily rainfall minimum prior to the average daily rainfall maximum. The minimum and maximum were derived using differing running average periods of 10, 30, 50, 70 and 90 days. By focusing on the minimum prior to the maximum rainfall we have focused purely on the wet season of the largest magnitude, if more are present. It should be noted that the parameter $d$ does not vary temporally but is taken from the climatological distribution of daily rainfall throughout the year. In Figure 2, the spatial variation of parameter $d$ is shown at $2.5^{\circ}$ spatial resolution for the period 1978-2002 using a running average period of 90 days. In this, as in subsequent figures, 'Julian' dates are given relative to the reference point of January 1 . Thus, in some regions, it can be noticed that values of $d$ in excess of 320 are present

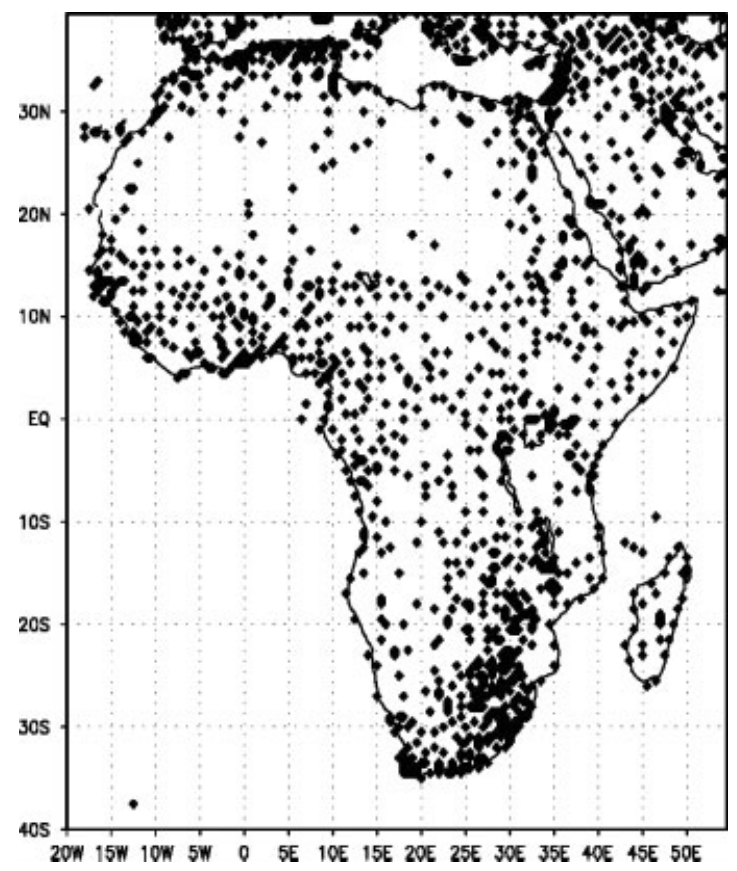

Figure 1. Location of GTS raingauge readings over Africa for the period 1978-2002.

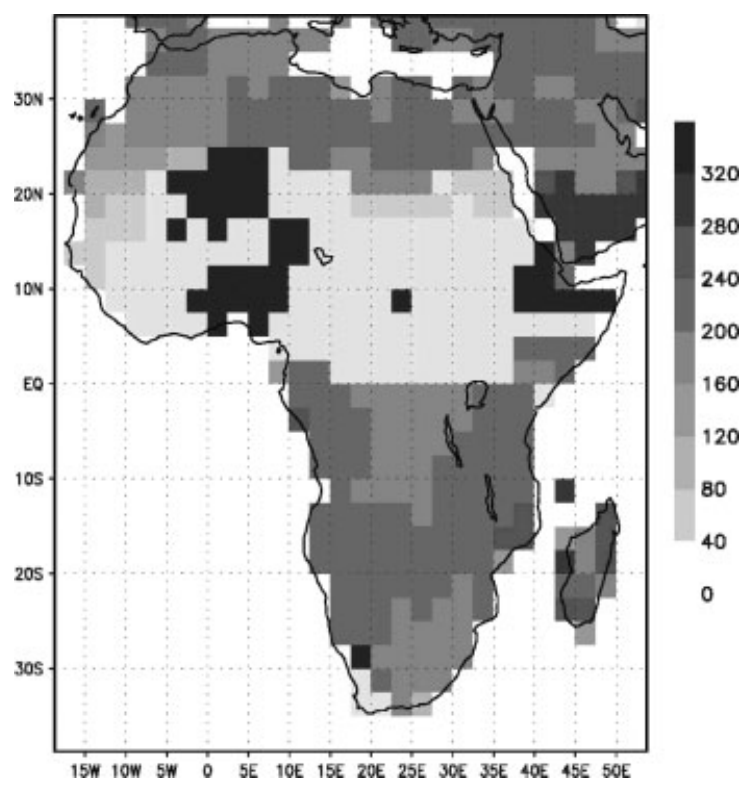

Figure 2. The spatial variation of parameter, $d$, calculated by taking the minimum 90-day running average prior to the maximum 90-day running average, is shown at $2.5^{\circ}$ spatial resolution for the period 1978-2002.

next to areas of $d$ values of $0-40$. This occurs as the dry period identified falls after or before the January 1 . In trying to retrieve the start of the wet season date it is important to have continuous daily data around the period examined. In Figure 3, the percentage of days for which there are rainfall data, 3 months after the $d$ date for the period 1978-2002 for each $2.5^{\circ}$ grid square are shown. The restriction of the data to within three months of the $d$ date allows a more accurate depiction of data availability for the calculation of the start of the wet season compared 


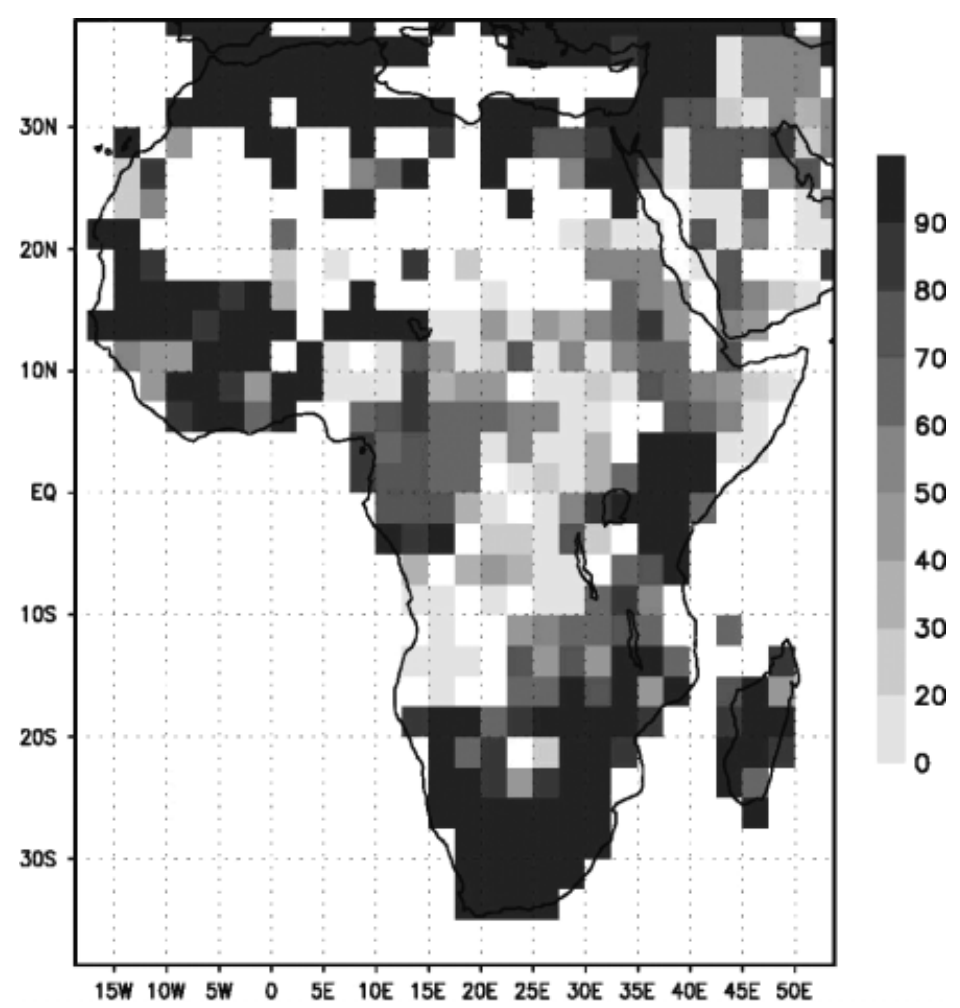

Figure 3. The percentage of the three-month period post the $d$ date for which there is daily rainfall data for each $2.5^{\circ}$ grid square from $1978-2002$.

to assessing data availability over the whole year. Linear trend analysis was performed on those start date data that were significantly (at 0.05 significance level) correlated with time for each $2.5^{\circ}$ latitude/longitude grid square. The sensitivity of the trends in wet season start dates to both the availability of continuous data and the averaging period used to define $d$ is discussed in Section 3.

The four other parameters that are used to define the start date are the amount of rainfall $(x)$ over a period $(t)$ to denote a possible start, the number of days $(n)$ of a dry spell and the number of days $(m)$ from the possible start date over which the dry spell re-classifies the start date as a false start. Three amounts of rainfall were chosen for $x$ : $10 \mathrm{~mm}, 20 \mathrm{~mm}$ and $30 \mathrm{~mm}$, as they encompass a broad range of crop water (rainfall) requirements. In order to maximize the variability of start dates the number of consecutive days over which an amount of rainfall can occur is restricted to 2 days (e.g. $10 \mathrm{~mm}$ in total over the 2 days). The dry spell length was kept at 10 days in the next 30 days from a possible start date, as suggested originally by Stern et al. (1982). In Figure 4 the average wet season start dates are shown at $2.5^{\circ}$ spatial resolution for the period 1978-2002 with a 10, 20 and $30 \mathrm{~mm}$ threshold for $x$. The parameter $d$ values were derived using a 90-day averaging period and only grid cells were used where rainfall data are available at least $70 \%$ of the time required to identify the start of the wet season. On average, the start dates for the $20 \mathrm{~mm}$ threshold definition are 30 days later than the $10 \mathrm{~mm}$ threshold, while the start dates for the $30 \mathrm{~mm}$ threshold are, on average, 13 days later than the $20 \mathrm{~mm}$. It should be noted that for most of the Sahara and Namibian deserts there are no values of start date of the wet season due to the threshold defining the start date not being exceeded for all years. Hereafter, these regions are ignored with reference to changes in start date over time. It should also be noted that there is a high degree of variability from year to year of start dates. The average range from the earliest to the latest start dates from 1978 to 2002 for the region of grid squares with at least $70 \%$ data availability are 116,129 and 142 days for the 10, 20 and $30 \mathrm{~mm}$ rainfall thresholds, respectively.

The influence of dry spells on the variability of start date of the wet season can be seen in Figure 5 with the difference of the average possible (i.e. wet season start date without false starts) and real (i.e. including false start date criteria) start dates of the wet season. In Figure 5, the threshold for defining a possible start and real start are both $10 \mathrm{~mm}$ over 2 days, and as is shown, above grid squares must have at least $70 \%$ data availability, and a 90-day averaging period is used to define $d$. The average possible start date using the $10 \mathrm{~mm}$ threshold to define start dates is 4 days earlier than the average real start date for the 1978-2002 period. However, this figure is skewed to a lower value as there are possible starts in the marginal areas in southwest Africa and North Africa that do not have corresponding real start dates. The spatial pattern of difference between average possible and real start dates shows many grid cells to have possible start dates up to 2 weeks prior to the real ones, with the exception of regions over Namibia, Botswana, South Africa and Zimbabwe, and North Africa (over Algeria and Morocco) where possible starts of up to 4 weeks earlier can be observed. 
(a)

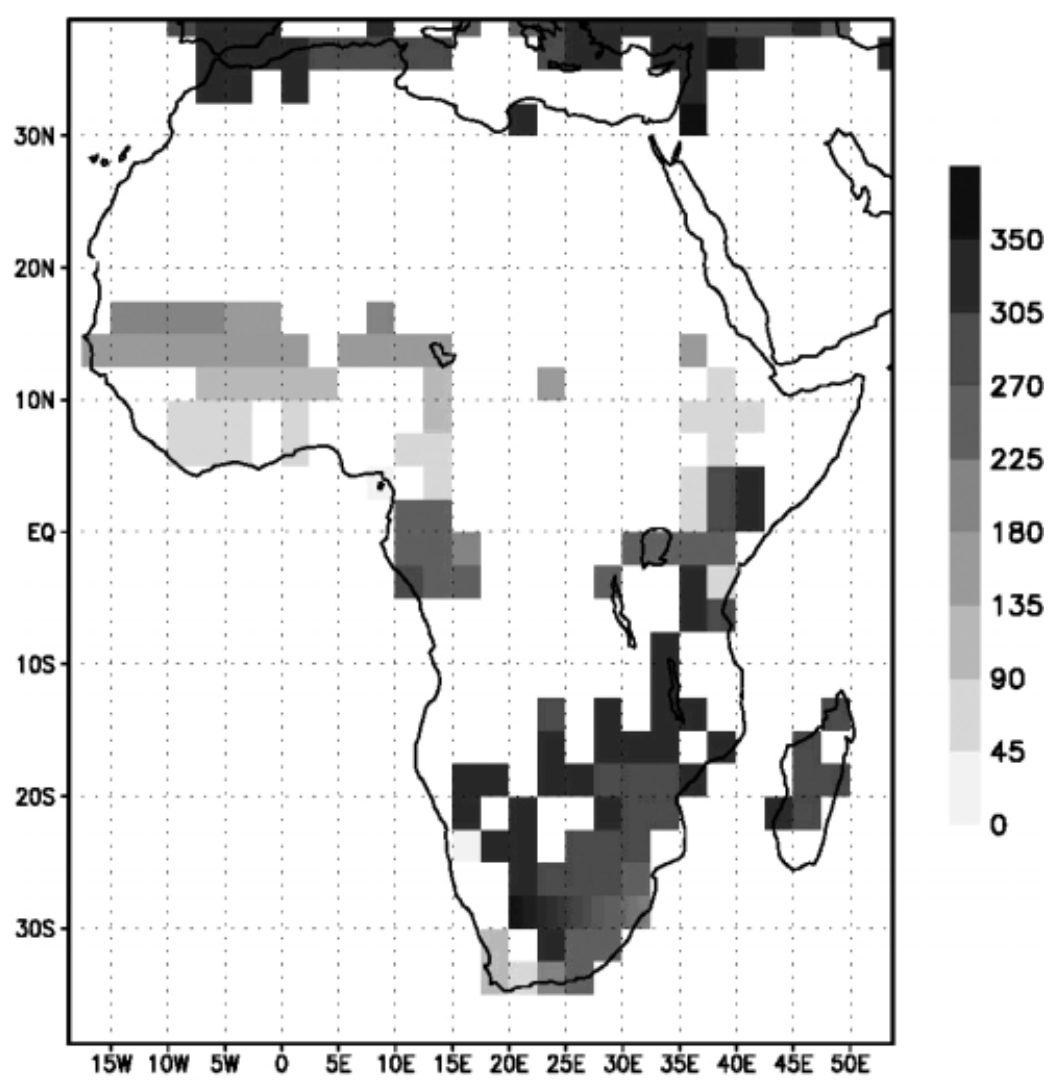

(b)

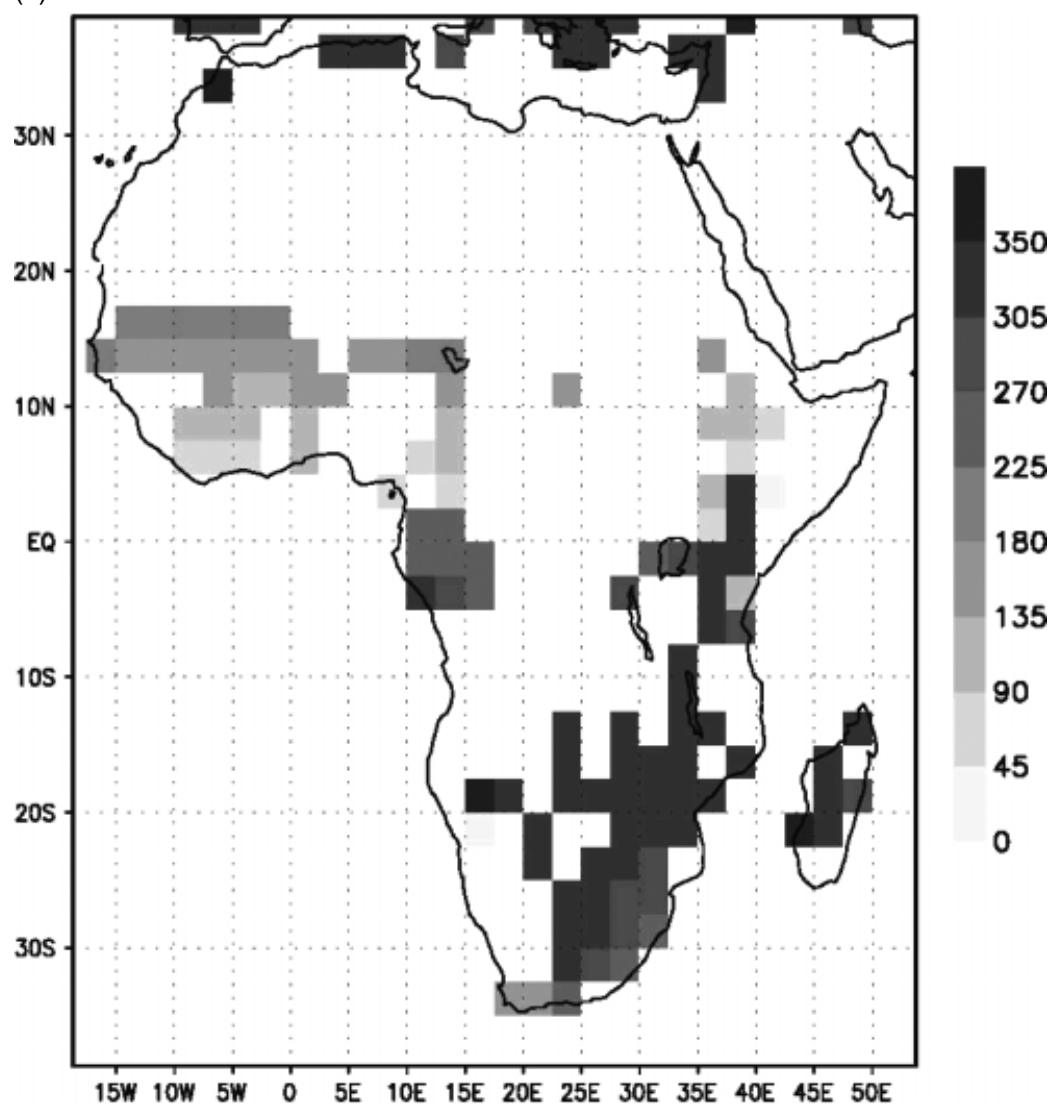

Figure 4. The average wet season start dates from January 1 are shown at $2.5^{\circ}$ spatial resolution for the period $1978-2002$ with a (a) $10 \mathrm{~mm}$, (b) $20 \mathrm{~mm}$ and (c) $30 \mathrm{~mm}$ thresholds, and $70 \%$ data availability. 


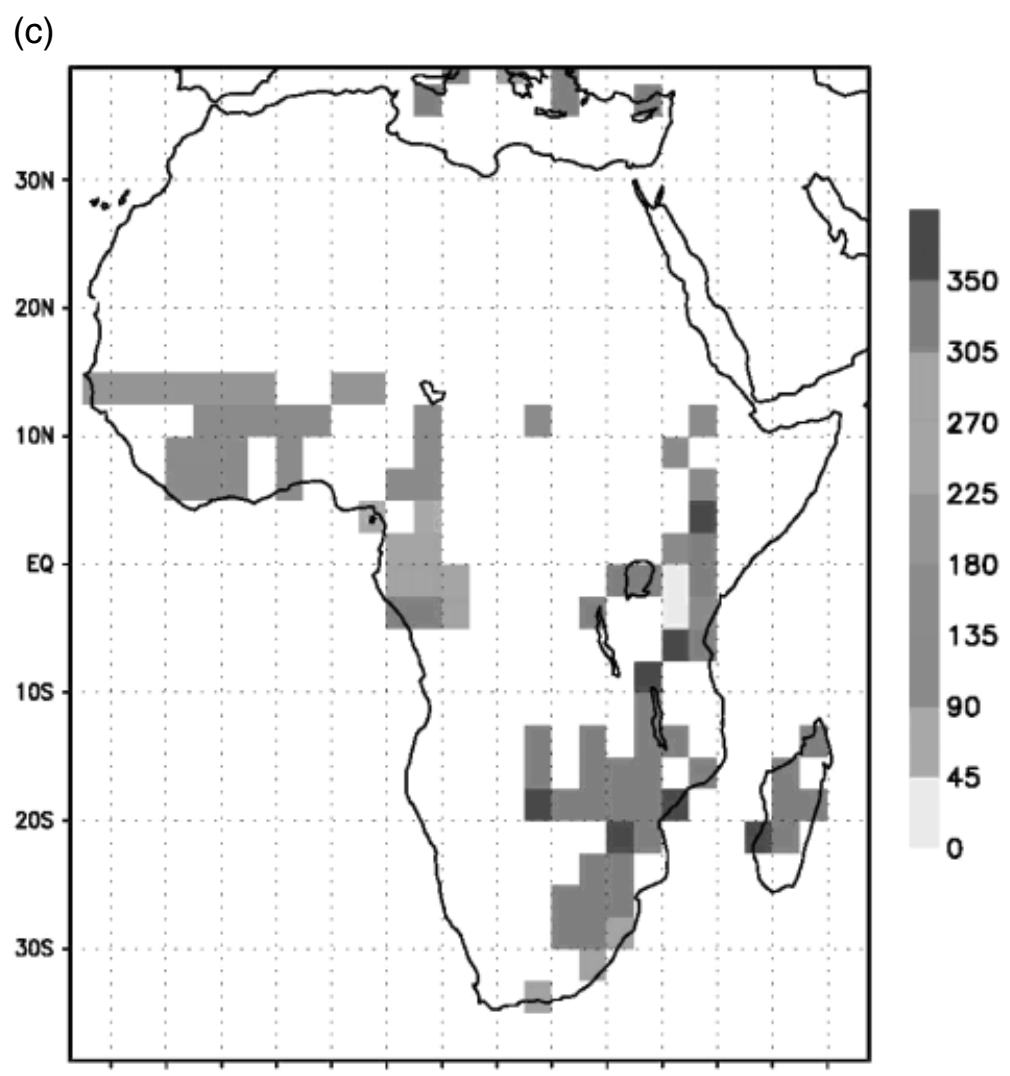

Figure 4. (Continued).

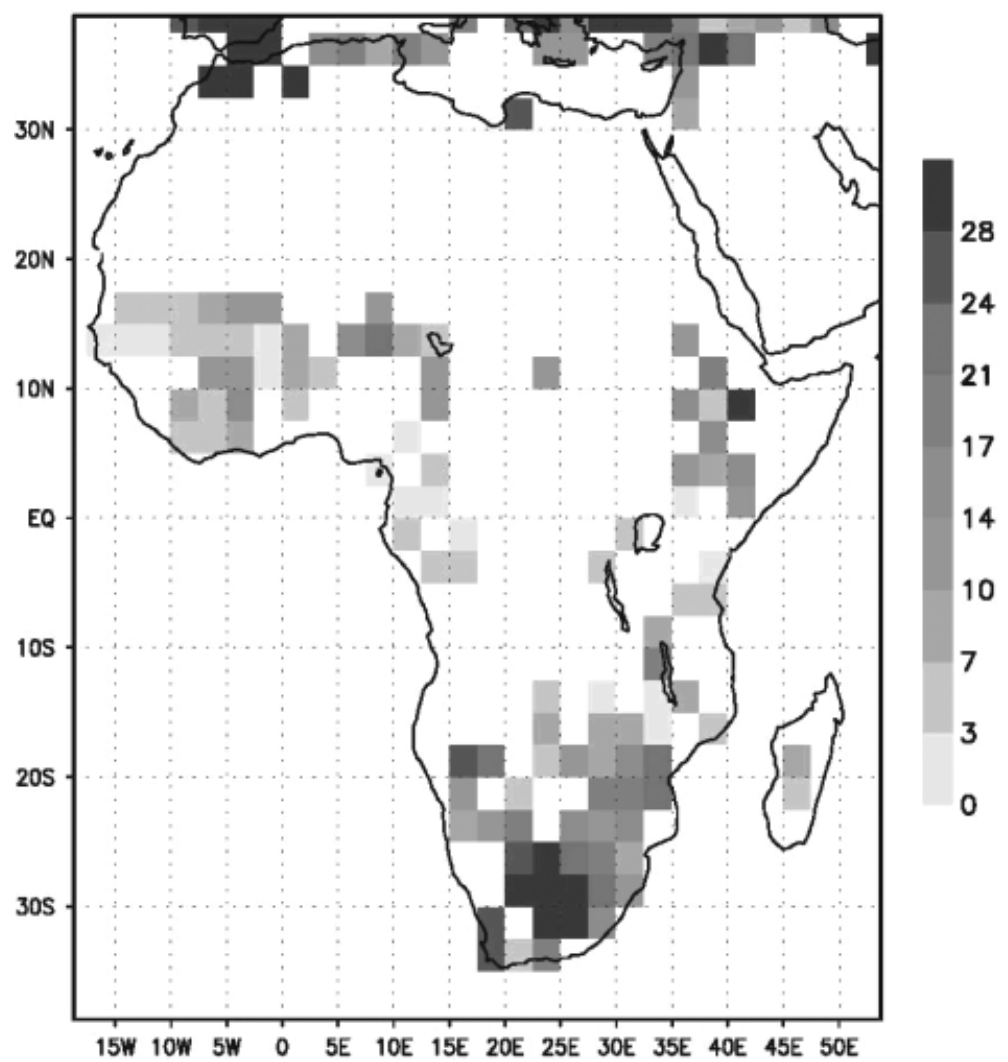

Figure 5. The difference between the average of start dates and possible start dates at $2.5^{\circ}$ spatial resolution for the period $1978-2002$ using a $10 \mathrm{~mm}$ rain threshold. 
D. R. KNIVETON ET AL.

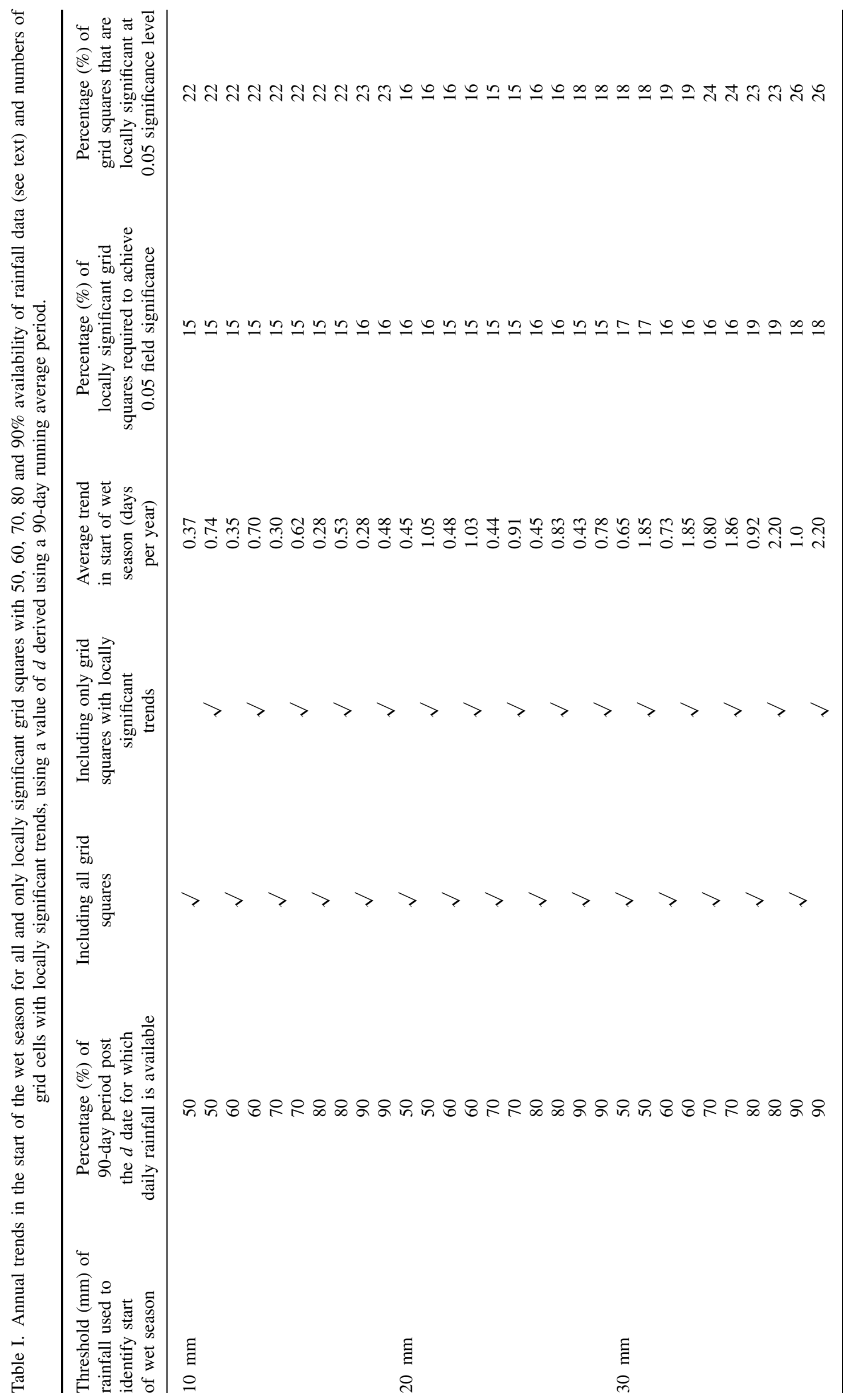




\section{Trends}

The change in temperature over Africa during the last 100 years has mirrored that shown by global datasets with a warming of $0.5^{\circ} \mathrm{C}$ century $^{-1}$. As with the global record, warming occurred rapidly in the 1910s-1930s and post 1970s (Hulme et al., 2001). Spatially, the warming trend has dominated most of the continent with some areas of cooling around Nigeria/Cameroon in West Africa and along the coastal areas of Senegal/Mauritania and South Africa. Trends in rainfall show a less coherent pattern of change than temperature with modest increases (up to $10 \%$ century $^{-1}$ ) in rainfall over most of equatorial Africa and the Red Sea coast (Hulme et al., 2001). Drying trends have been most pronounced $\left(>25 \%\right.$ century $^{-1}$ ) over some eastern and western parts of Sahel, with more modest drying trends along the Mediterranean coast and over large parts of Botswana, Zimbabwe and the Transvaal in South Africa (Hulme et al., 2001).

In Table I, the trends in the start dates of the wet season, in units of days per year, with 10,20 and $30 \mathrm{~mm}$ thresholds determining the start dates, are shown for locally significant trends (at 0.05 significance level) and for all trends for grid squares where rainfall data is available for at least 50,60,70,80 and $90 \%$ of the time required to identify the start of the wet season.
Additionally shown are the percentages of grid cells with significant trends required to achieve field significance, along with the percentages measured. Field significance is measured at the 0.05 significance level, and takes into account the impact of spatial correlation in the data (Livezey and Chen, 1983). Noticeably, all the trends have field significance for 10,20 and $30 \mathrm{~mm}$, and for grid squares where data availability is over $50,60,70,80$ and $90 \%$ of the time in a 90-day period after the start date. This illustrates the robustness of the finding that, for Africa as a whole, the start of the wet season is getting progressively later each year. Interestingly, the influence of data availability on trends in the start date of the wet season varies with rainfall threshold. For the 10 and $20 \mathrm{~mm}$ rainfall thresholds the trends get smaller in magnitude with the consideration of locations with more complete datasets. Whilst for a $30 \mathrm{~mm}$ rainfall threshold the magnitude of the trend gets larger as a tighter restriction is placed on the data availability. However, for all thresholds the percentage of grid squares that have significant trends increases with increased data completeness. This possibly indicates that with more data an increasing trend in the start of the wet season would be seen more over more of Africa. In Figure 6, the trends in start dates of the wet season for 1978-2002 are shown using a 10, 20, and $30 \mathrm{~mm}$ threshold, and an averaging period of 90 days for the determination

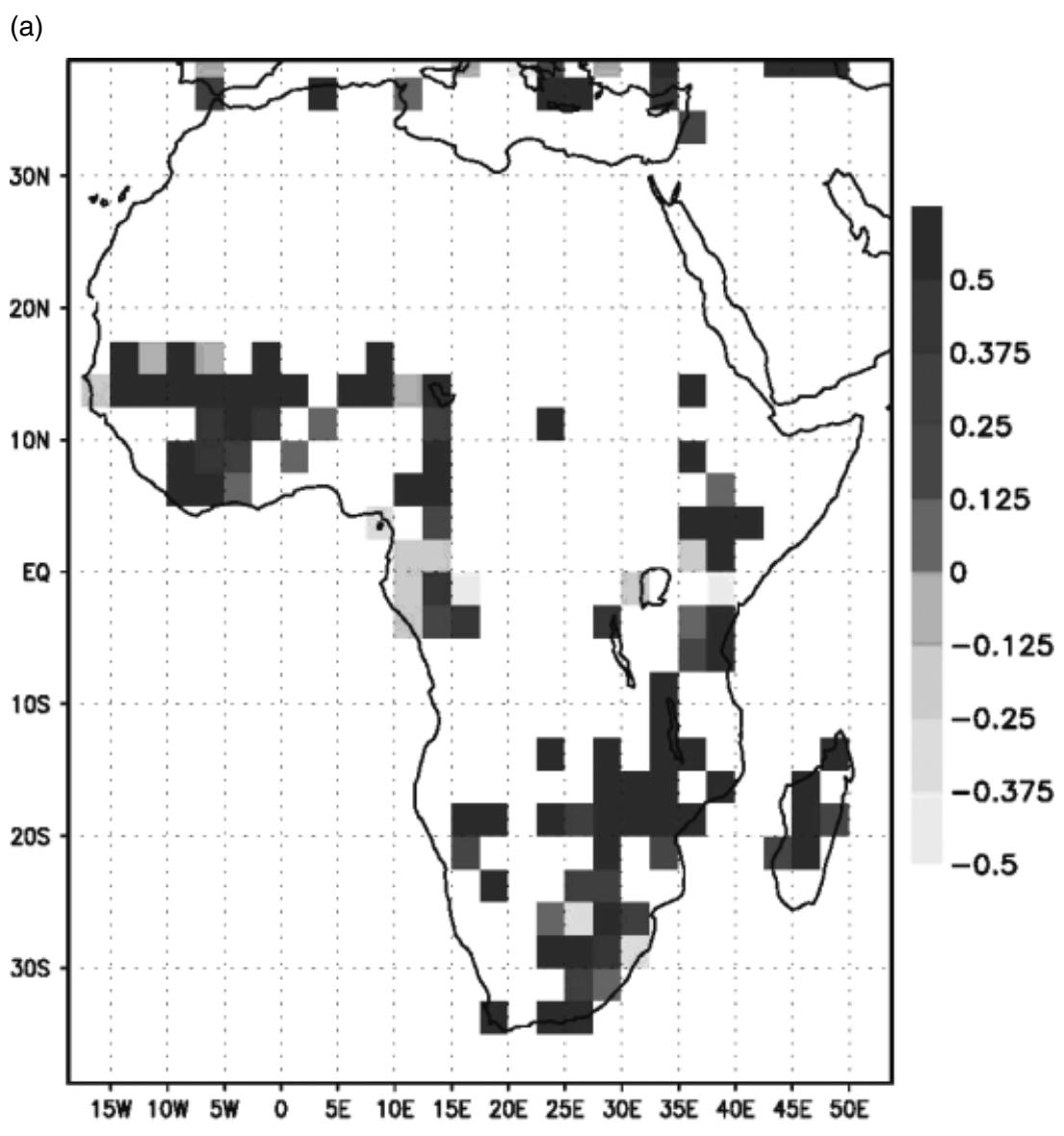

Figure 6. Linear trends in start dates of the wet season (days per year) calculated over the period 1978-2002 using a threshold of (a) 10 mm, (b) $20 \mathrm{~mm}$ and (c) $30 \mathrm{~mm}$ to define the start date and only for grid squares with $70 \%$ data availability. 
(b)

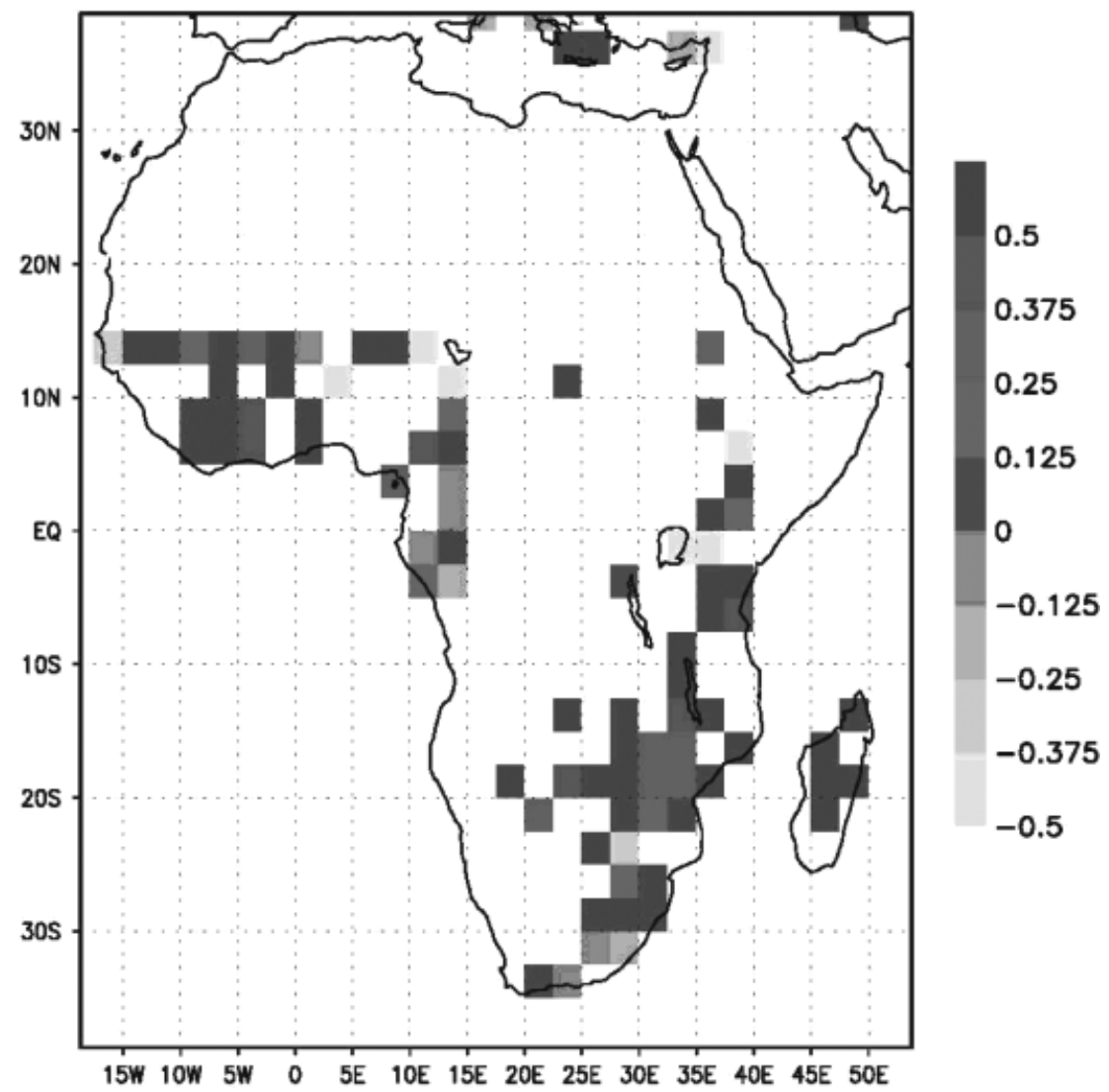

Figure 6. (Continued).

of $d$, and $70 \%$ data availability. For much of Africa there is a pattern of later dates for the start of the wet season during the 25-year period. Exceptions to this are patches of earlier start dates over equatorial Africa, West Africa and isolated locations in southern Africa over Namibia, South Africa, Mozambique and Madagascar. Estimates of the average trend in the start of the wet season range from 0.28 to $0.37,0.43$ to 0.48 and 0.65 to 1.0 days per year, for 10,20 , and $30 \mathrm{~mm}$ thresholds, with the percentage of rainfall data available varying from 50 to $90 \%$. Of the grid squares which are locally significant (at the 0.05 level) estimates of the average trend in the start of the wet season range from 0.53 to $0.74,0.78$ to 1.05 and 1.85 to 2.2 days per year for 10,20 , and $30 \mathrm{~mm}$ thresholds, with the percentage of rainfall data available varying from 50 to $90 \%$. The sensitivity of the trends to the length of averaging period used to define the $d$ value is given in Table II for a $10 \mathrm{~mm}$ threshold and $70 \%$ data availability. These data show the trends to be relatively insensitive to the averaging period used to define $d$, with trends varying from 0.29 to 0.31 days per year. In Figure 7 , time series are shown of the average start date of the wet season for West and southern Africa as contained by the latitude-longitude boxes of $5^{\circ}-20^{\circ} \mathrm{N}, 20^{\circ} \mathrm{W}-15^{\circ} \mathrm{E}$ and $35^{\circ}-10^{\circ} \mathrm{S}, 15^{\circ}-50^{\circ} \mathrm{E}$, respectively, for grid squares which are significantly (at the 0.05 level) correlated with time. These clearly show the trend towards latter start

dates in both regions and the high variability of start dates from year to year.

\section{Discussion and conclusion}

For regions that rely on rain-fed agriculture, the start date of the wet season is a fundamental piece of information that aids decision making at a number of levels, from the individual farmer to inter-governmental organisations responsible for regional food supply. In this study, we have chosen to base the definition for identifying the start of the wet season around the rainfall distribution.

Table II. Annual trends in the start of the wet season for grid squares with $70 \%$ availability of rainfall data (see text), using a value of $d$ derived using a 10,30,50, 70 and 90-day running average period. The threshold for defining the start of the wet season was set at $10 \mathrm{~mm}$.

Length of average

period for calculating $d$ (days)
Average trend in start of wet season (days per year)

\begin{tabular}{ll}
\hline 10 & 0.29 \\
30 & 0.30 \\
50 & 0.31 \\
70 & 0.30 \\
90 & 0.30 \\
\hline
\end{tabular}




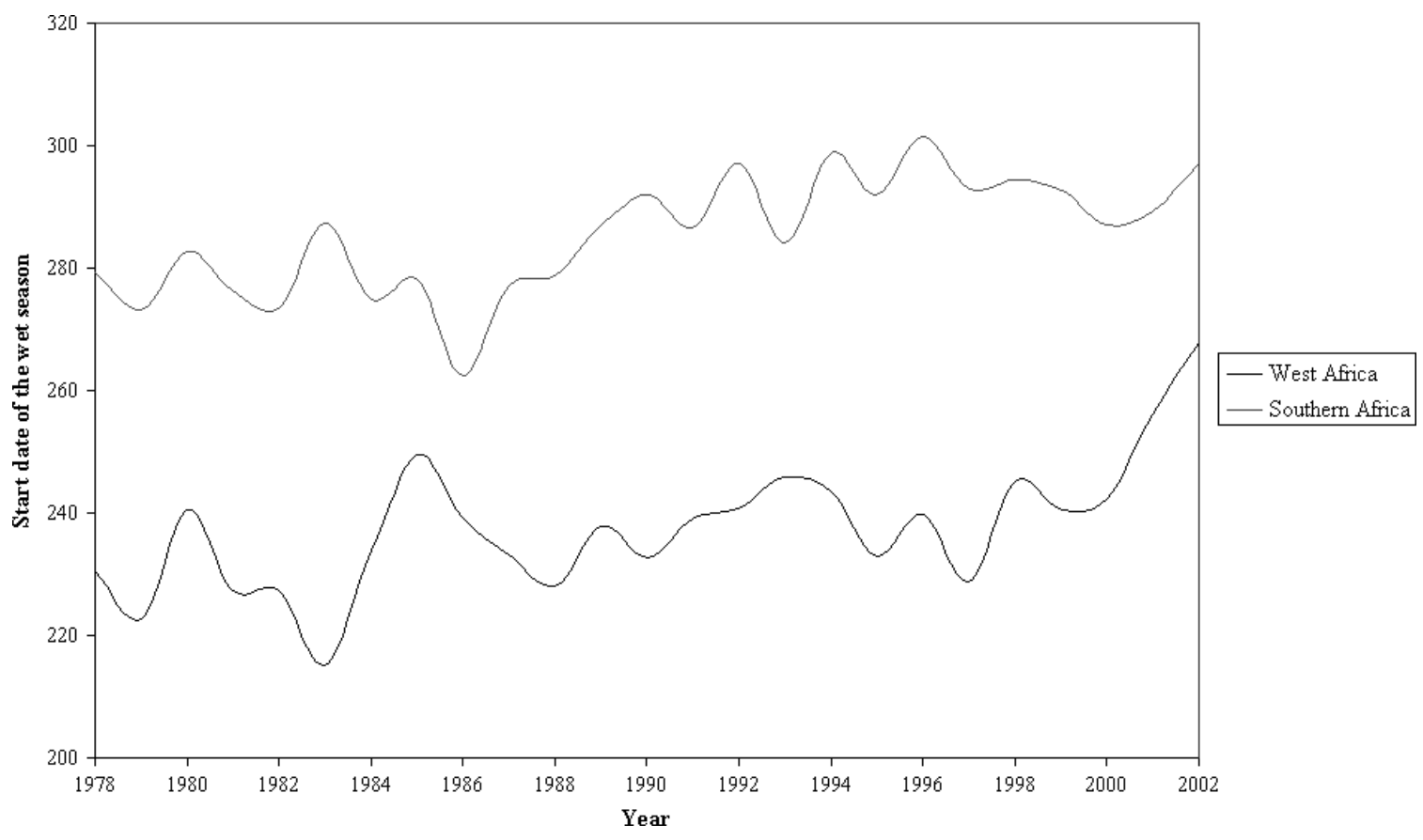

Figure 7. Time series of the average start date of the wet season for West and southern Africa as contained by the latitude/longitude boxes of $5^{\circ}-20^{\circ} \mathrm{N}, 20^{\circ} \mathrm{W}-15^{\circ} \mathrm{E}$ and $35^{\circ}-10^{\circ} \mathrm{S}, 15^{\circ}-50^{\circ} \mathrm{E}$ respectively, for grid squares which are significantly (at the 0.05 level) correlated with time.

The derivation of several start date databases for Africa at a $2.5^{\circ}$ spatial resolution, using different thresholds of rain required to define the onset of the wet season, has allowed the investigation of the existence of trends in these dates over a recent quarter of a century.

The start dates of the wet season over much of Africa exhibit large variability both temporally and geographically. In general, start date temporal variability increases with increased rainfall needed to define the start date (i.e. the wetter part of the wet season). In terms of climate change, over much of Africa the wet season appears to have started later in the year, from 1978 to 2002 , by up to 4 days a year in some locations, and by an average of $0.28-0.37,0.43-0.48$ and $0.65-1.0$ days per year for 10,20 , and $30 \mathrm{~mm}$ thresholds chosen to define the start of the wet season. Taking the average of these estimates reveals that the start of the wet season has, on average, arrived 9, 12 and 21 days later in the early part of this millennium compared to 25 years previously, for rainfall thresholds of 10,20 and $30 \mathrm{~mm}$ respectively.

Future research into the occurrence of the wet season should examine causes of variability of the start date from year to year, and information on the cessation dates of the wet season as well as the frequency of dry breaks in between start and end dates. Several caveats to this study should be stated. First, the data used to define the start dates of the wet season only covers a minority of the whole of Africa and surrounding regions. Second, it should be noted that the data from which these trends are derived is relatively short, at 25 years, and analysis of longer datasets when available, may temper the conclusions drawn from this analysis. Finally, no attempt in this study has been made to explore the variability of the start of the wet season over the Sahara or Namibian deserts where consistent arrival of the wet season does not occur and data availability is poor.

\section{Acknowledgements}

The authors would like to thank Pingping Xie and Tim Love of the Climate Prediction Center USAID/FEWSNET Project at National Oceanic and Atmospheric Administration (NOAA) for the gridded rainfall datasets.

\section{References}

Benoit P. 1977. The start of the growing season in northern Nigeria. Agricultural Meteorology 18: 91-99.

Camberlin P, Janicot S, Poccard I. 2001. Seasonality and atmospheric dynamics of the teleconnection between African rainfall and tropical sea-surface temperature: Atlantic vs. ENSO. International Journal of Climatology 21(8): 973-1005.

Cook KH. 2000. The South Indian convergence zone and interannual rainfall variability over southern Africa. Journal of Climate 13(21): 3789-3804.

Cook KH. 2001. A Southern Hemisphere wave response to ENSO with implications for southern Africa precipitation. Journal of the Atmospheric Sciences 58(15): 2146-2162.

Davy E, Mattei GF, Solomon SL. 1976. An evaluation of the climate of water resources for development of agriculture in the SudanoSahelian Zone of West Africa. Special Environmental Report 9. World Meteorological Organistaion: Geneva, Switzerland, WMO-No 459.

Dodd DES, Jolliffe IT. 2001. Early detection of the start of the wet season in semiarid tropical climates of Western Africa. International Journal of Climatology 21(10): 1251-1262.

Fontaine B, Philippon N, Trzaska S, Roucou P. 2002. Spring to summer changes in the West African monsoon through NCEP/NCAR reanalyses (1968-1998). Journal of Geophysical Research-Atmospheres 107(D14): 101029-101037 art. no. 4186.

Gallee H, Moufouma-Okia W, Bechtold P, Brasseur O, Dupays I, Marbaix P, Messager C, Ramel R, Lebel T. 2004. A high-resolution simulation of a West African rainy season using a regional climate model. Journal of Geophysical Research-Atmospheres 109(D5): D05108.1-D05108.13. 
Gissila T, Black E, Grimes DIF, Slingo JM. 2004. Seasonal forecasting of the Ethiopian summer rains. International Journal of Climatology 24(11): $1345-1358$

Goddard L, Graham NE. 1999. Importance of the Indian Ocean for simulating rainfall anomalies over eastern and southern Africa. Journal Of Geophysical Research-Atmospheres 104(D16): 19099-19116.

Hulme M. 1987. Secular changes in wet season structure in central Sudan. Journal of Arid Environments 13: 31-46.

Hulme M, Doherty R, Ngara T. 2001. African climate change: 1900-2100. Climate Research 17(2): 145-168.

Ingram KT, Roncoli MC, Kirshen PH. 2003. Opportunities and constraints for farmers of west Africa to use seasonal precipitation forecasts with Burkina Faso as a case study. Agricultural Systems 74(3): 331-349.

Janicot S, Harzallah A, Fontaine B, Moron V. 1998. West African monsoon dynamics and eastern equatorial Atlantic and Pacific SST anomalies (1970-88). Journal of Climate 11(8): 1874-1882.

Landman WA, Mason SJ. 1999. Operational long-lead prediction of South African rainfall using canonical correlation analysis. International Journal of Climatology 19(10): 1073-1090.

Livezey RE, Chen WY. 1983. Statistical field significance and its determination by Monte Carlo techniques. Monthly Weather Review 111: $46-59$.

Nicholson SE, Entekhabi D. 1987. Rainfall variaibility in equatorial and southern Africa-relationships with seas-surface temperatures along the southwestern coast of Africa. Journal of Climate and Applied Meteorology 26(5): 561-578.

Ntale HK, Gan TY, Mwale D. 2003. Prediction of East African seasonal rainfall using simplex canonical correlation analysis. Journal of Climate 16(12): 2105-2112.
Ogallo LJ. 1988. Relationships between seasonal rainfall in east-Africa and the southern oscillation. Journal of Climatology 8(1): 31-43.

Otterman J. 1974. Baring high-albedo soils by overgrazing- hypothesized desertification mechanism. Science 186(4163): 531-533.

Reason CJC. 1999. Warm and cold events in the southeast Atlantic southwest Indian Ocean region and potential impacts on circulation and rainfall over southern Africa. Meteorology and Atmospheric Physics 69(1-2): 49-65.

Rouault M, Florenchie P, Fauchereau N, Reason CJC. 2003. South East tropical Atlantic warm events and southern African rainfall. Geophysical Research Letters 30(5): CLI9.1-CLI9.4.

Rowell DP. 2003. The impact of Mediterranean SSTs on the Sahelian rainfall season. Journal of Climate 16(5): 849-862.

Semazzi FHM, Burns B, Lin NH, Schemm JK. 1996. A GCM study of the teleconnections between the continental climate of Africa and global sea surface temperature anomalies. Journal of Climate 9(10): 2480-2497.

Stern RD, Dennett MD, Dale IC. 1982. Analysing daily rainfall measurements to give agronomically useful results. I. Direct methods. Experimental Agriculture 18: 223-236.

Tennant W. 1999. Numerical forecasting of monthly climate in southern Africa. International Journal of Climatology 19(12): 1319-1336.

Thiaw WM, Barnston AG, Kumar V. 1999. Predictions of African rainfall on the seasonal timescale. Journal Of Geophysical ResearchAtmospheres 104(D24): 31589-31597.

Vizy EK, Cook KH. 2001. Mechanisms by which Gulf of Guinea and eastern North Atlantic sea surface temperature anomalies can influence African rainfall. Journal of Climate 14(5): 795-821.

Ziervogel G, Calder R. 2003. Climate variability and rural livelihoods: assessing the impact of seasonal climate forecasts in Lesotho. Area 35(4): 403-417. 